\title{
Isolation and Characterization of Haloalkaliphilic Bacteria Isolated from the Rhizosphere of Dichanthium annulatum
}

\author{
Salma Mukhtar ${ }^{1}$, Kauser Abdulla Malik ${ }^{1}$ and Samina Mehnaz ${ }^{1}$ \\ ${ }^{1}$ Department of Biological Sciences, Forman Christian College (A Chartered University), Ferozepur Road, Lahore 54600, Pakistan
}

Received: July 25, 2018; Accepted: July 27, 2018; Published: July 31, 2018

*Corresponding author: Salma Mukhtar, Department of Biological Sciences, Forman Christian College (A Chartered University),Ferozepur Road, Lahore 54600, Pakistan, Telephone: +92-42-99231581, E-Mail: salmamukhtar85@gmail.com

\begin{abstract}
Diversity of haloalkaliphilic bacteria from the rhizosphere of halophytes is a crucial determinant of plant health and productivity. The main objective of this study is the identification and characterization of haloalkaliphilic bacteria from the rhizosphere, rhizoplane and root endosphere of $D$. annulatum collected from Khewra Salt Mine, Pakistan. A total of 41 bacterial strains were isolated and identified on the basis of morphological and biochemical characterization. Twenty two strains were selected for phylogenetic analysis based on 16S rRNA gene sequences. About $41 \%$ bacterial strains were identified as different species of Bacillus. Exiguobacterium, Kocuria, Citricoccus and Staphylococcus were dominant genera identified in this study. Most of the bacterial strains characterized in this study were alkaliphilic, moderately halophilic and mesophilic in nature. Mostly strains were considered as a good source of hydrolytic enzymes because of their ability to degrade proteins, carbohydrates and lipids. Results for screening of hydrolytic enzymes showed that more than $90 \%$ strains had ability to produce at least three enzymes screened in this study. These results showed that haloalkaliphilic bacterial diversity identified in this study had great biotechnological potential.
\end{abstract}

Keywords: Haloalkaliphilic bacteria; rhizosphere; 16S rRNA gene; Dichanthium annulatum; hydrolytic enzymes

\section{Introduction}

Hypersaline environments are widely distributed across the globe as salt mines, saline lakes, salt marshes and marine water [1, 2]. Halophytes such as Atriplex, Salsola, Dichanthium, kallar grass and para grass may contribute significantly to the developing world's supply of food, fiber, fuel and fodder. For areas where farm land has been salinized by poor irrigation practices or that overlie reservoirs of brackish water or for coastal desert regions, these plants could be successfully grown $[3,4]$.

The rhizosphere of halophytes harbors an impressive array of halophilic and alkaliphilic microorganisms. Poly extremophilic organisms have ability to tolerate two or more extreme conditions, such as haloalkaliphiles, halothermophiles and alkalithermophiles [5]. Haloalkaliphiles are organisms that require high salinity (3-30\%) and an alkaline $\mathrm{pH}(\mathrm{pH} 9-13)$ for their growth [6]. These organisms have been isolated and characterized from a number of environments such as saline- sodic lakes, acid mines, hypersaline saline soils, salt mines, marine environments and salt marshes [7, 8]. Haloalkaliphiles usually use small organic molecules (osmolytes, e.g., ectoine, betaine and proline) and intracellular enzymes ( $\alpha$-galactosidase) to maintain their osmotic balance and $\mathrm{pH}$ ranges near neutral to survive under extreme saline and basic environments $[9,10]$

Haloalkaliphiles have a wide range of applications in biodefense, bioenzymes and biofuel production [11, 12]. These organisms provide a good source of novel alkaliphilic and halophilic enzymes such as proteases, gelatinase, amylases, lipases, cellulases and xylanases [13, 14]. Enzymes isolated and characterized from haloalkaliphiles have ability to function properly even at high $\mathrm{pH}$ and salinity. These enzymes can be used in industrial applications such as detergent industry, food stuffs, paper and pulp and pharmaceuticals industry $[15,16]$.

Though a number of studies have been reported on the isolation of haloalkaliphiles from different environments but this study is the first report on characterization of haloalkaliphilic bacteria from the rhizosphere of Dichanthium annulatum (halophyte) collected from Khewra Salt Mines, Pakistan. In the present study, haloalkaliphilic bacteria were isolated from rhizospheric soil and roots and identified on the basis of $16 \mathrm{~S}$ rRNA gene sequence analysis. Selected haloalkaliphilic bacterial strains were further characterized for their biotechnological potential and ability to produce different industrially important enzymes (cellulases, proteases, amylases, xylanases and lipases).

\section{Material and Methods}

\section{Sampling site}

Khewra Salt Mine is the world second largest salt mine, It is located near Jhelum District, Punjab, Pakistan $\left(32^{\circ} 38^{\prime}\right.$ North latitude, $73^{\circ} 10^{\prime}$ East longitude). It is classified as thalassic hypersaline environment because it is derived from evaporation of sea water [17]. It has $\mathrm{Na}+$ and $\mathrm{Cl}$ - dominating ions and the $\mathrm{pH}$ is near neutral to slightly alkaline. Vegetation of this area is classified as sub-tropical dry evergreen forest. Plants like Suaeda, 
Salsola, Atriplex, Dichanthium, Justica, Lantana, and Chrysopogon are dominant genera found here.

\section{Sample collection}

Rhizospheric soil samples were collected by gently removing the plants and obtaining the soil attached the roots. Soil and root samples were collected four sites from different sites of Khewra Salt Mine. At each site, soil samples of approximately $500 \mathrm{~g}$ were collected in black sterile polythene bags. These samples were stored at $4^{\circ} \mathrm{C}$ for further analysis.

\section{Soil physicochemical parameters}

Each soil sample (300 g) was thoroughly mixed and sieved through a pore size of $2 \mathrm{~mm}$. Physical properties $(\mathrm{pH}$, moisture content, salinity and temperature) of soil samples from different plants and non-rhizospheric soils samples were determined. Moisture (\%); temperature and texture class were measured by Anderson method [18]; pH was measured by 1:2.5 (w/v) soil to water mixture and electrical conductivity $(\mathrm{dS} / \mathrm{m})$ was measured by $1: 1(\mathrm{w} / \mathrm{v})$ soil to water mixture at $25^{\circ} \mathrm{C}$ [19]. Organic matter (Corg) was calculated by Walkley-Black method [20]. Cation exchange capacity (CEC) is capacity to retain and release cations $\left(\mathrm{Ca}^{2+}, \mathrm{Mg}^{2+}, \mathrm{K}^{+}\right.$and $\left.\mathrm{Na}^{+}\right)$and sodium adsorption ratio (SAR) is the measure of the sodicity of soil which is calculated as the ratio of the sodium to the magnesium and calcium.

\section{Isolation of haloalkaliphilic bacteria}

Haloalkaliphilic Medium (HaP) (Tryptone $5 \mathrm{~g} / \mathrm{l}$, Yeast Extract $1 \mathrm{~g} / \mathrm{l}, \mathrm{NaCl} 30 \mathrm{~g} / \mathrm{l}, 5 \mathrm{~g} / \mathrm{l} \mathrm{KCl}, 10 \mathrm{~g} / \mathrm{l} \mathrm{MgSO}_{4}, 2 \mathrm{~g} / \mathrm{l} \mathrm{K}_{2} \mathrm{HPO}_{4}$ and $\mathrm{pH}$ 9.2) was used for the isolation and purification of bacteria present in saline environments [21]. Rhizosphere was fractionated into rhizosphere fraction (RS), rhizoplane fraction (RP) and root endosphere or histoplane bacterial fraction (HP) according to the method described by Malik et al. [22]. RS fraction indicates the soil adhering with the roots; RP fraction is the root surface and HP is the interior of roots. In case of RS, the soil was mixed thoroughly, sieved and then one gram representative soil sample was taken. Bacterial fraction from RP was isolated by shifting one gram of washed root to a falcon tube containing $9 \mathrm{ml}$ saline along with some pebbles and incubated in a shaker for 30 minutes. For the isolation of HP bacteria roots was sealed at both ends with wax after washing with water. Sealed roots were surface sterilized by using $10 \%$ bleach for $10 \mathrm{~min}$. After sterilization waxed ends of roots were removed and roots were macerated by using FastPrep® instrument (MP Biomedicals). The soil from each non-rhizospheric soil samples and brine lake-bank soil samples was mixed thoroughly, sieved and then one gram representative soil sample was taken. Serial dilutions $\left(10^{-1}-10^{-10}\right)$ were made for all samples [23]. Dilutions from 10-3 to 10-6 were inoculated on HaP plates for counting colony forming units (CFU) per gram of dry weight. Plates were incubated at $30^{\circ} \mathrm{C}$ until the appearance of bacterial colonies. Bacterial colonies were counted and number of bacteria per gram sample was calculated. The bacteria were purified by repeated sub-culturing of single colonies. Single colonies were selected, grown in HaP broth and stored in 33\% glycerol at $-80^{\circ} \mathrm{C}$ for subsequent characterization.

\section{Morphological and biochemical characterization of haloalkaliphilic bacterial isolates}

For morphological characterization, colony morphology (colour, shape, elevation, size and margin) and cell morphology (shape, size, motility and Gram-staining) were studied. Halophilic bacterial strains were biochemically characterized to detect different enzymes ( $\beta$-galactosidase, arginine deaminase, lysine decarboxylase, tryptophan deaminase, gelatinase, catalase and oxidase) and carbon sources (glucose, sucrose, mannitol, maltose, arabinose, lactose and sorbitol) utilization by using QTS 24 strips (DESTO Laboratories, Karachi, Pakistan).

\section{Molecular characterization of haloalkaliphilic bacterial isolates}

Genomic DNA was isolated from different bacterial isolates by CTAB method [24]. PCR amplification of 16S rRNA were performed by using universal forward and reverse primers P15(5'-GAGAGTTTGATCCTGGTCAGAACGAAC-3'),P65 (5'CGTACGGCTACCTTGTTACGACTTCACC-3') for prokaryotes [25]. A PCR reaction of $25 \mu \mathrm{l}$ was prepared by using Taq polymerase (5U) $0.5 \mu \mathrm{l}$, Taq buffer (10X) $1 \mu \mathrm{l}, \mathrm{MgCl} 2$ (25 mM) $1.5 \mu \mathrm{l}$, dNTPS $(2.5 \mathrm{mM}) 2 \mu \mathrm{l}, 2 \mu \mathrm{l}$ each of forward and reverse primer (10 pmol), $16 \mu \mathrm{l}$ of dd. $\mathrm{H}_{2} \mathrm{O}$ and $2 \mu \mathrm{l}$ of template DNA. First denaturation step at $95^{\circ} \mathrm{C}$ for $5 \mathrm{~min}$ followed by 30 cycles of $94^{\circ} \mathrm{C}$ for $1 \mathrm{~min}, 54^{\circ} \mathrm{C}$ for $1 \mathrm{~min}$ and $72^{\circ} \mathrm{C}$ for $2 \mathrm{~min}$ and a final extension step was at $72^{\circ} \mathrm{C}$ for $10 \mathrm{~min}$. PCR products were analyzed by using $1 \%$ agarose gel. PCR products were purified by using GeneJET PCR Purification Kit (K0702 - Thermo Fisher Scientific). Purified PCR products were sequenced by using forward and reverse primers (Eurofins, Germany).

Sequences of 16S rRNA gene were assembled and analyzed with the help of Chromus Lite 2.01 sequence analysis software (Technelysium Pty Ltd. Australia). The gene sequences were compared to those deposited in the GenBank nucleotide database using the NCBI BLAST program. Sequences were aligned using Clustal X 2.1 program and phylogenetic tree was constructed using neighbor-joining method. Bootstrap confidence analysis was performed on 1000 replicates to determine the reliability of the distance tree topologies obtained [26]. The evolutionary distances were computed using the Neighbor-joining method [27]. Phylogenetic analyses were conducted in MEGA7 [28]. There were a total of 1434 positions in the final dataset. Sequence of $16 \mathrm{~S}$ rRNA gene from Micrococcus luteus was sued as outgroup. Bacterial strains identified in this study were submitted in GenBank under the accession numbers MH489029-MH489050.

\section{Screening of haloalkaliphilic bacterial strains with respect to their salt, $\mathrm{pH}$ and temperature}

\section{Tolerance Ability}

Bacterial isolates were grown in the presence of different salt 
concentrations ( $3-12 \% \mathrm{NaCl}), \mathrm{pH}$ ranges of $4-12$ and temperature ranges of $4-42^{\circ} \mathrm{C}$ by using $\mathrm{HaP}$ broth medium. Isolates were cultured in $250 \mathrm{ml}$ flasks at $30^{\circ} \mathrm{C}$ with continuous rotatory agitation at $150 \mathrm{rpm}$ for $72 \mathrm{~h}$ (hours) [29]. During incubation, bacterial growth in terms of optical density (OD 600) was measured after different time intervals $(3,6,12,24,48$ and $72 \mathrm{~h})$.

\section{Enzyme assays for haloalkaliphilic bacterial strains}

Cellulose and amylase activities were identified by using $2 \%$ iodine solution and spotting single colony of the bacterial strains on CMC (carboxymethyl cellulose 1\%) and starch (1\%) supplemented LB agar plates respectively [30]. Protease activity was tested on the medium described by Kumar et al. [31]. Test for gelatin hydrolysis was performed by using the method described by Pitt and Dey [32]. Lipase activity was tested by using HaP medium with $1 \%$ butyrin and Tween 80 hydrolysis assay as described by Sierra [33]. Xylanase activity was tested by using HaP medium supplemented with $1 \%$ xylan [34]. The clear zones around the bacterial colonies after 4-12 days of incubation at $30^{\circ} \mathrm{C}$ were considered as a positive result of protease, cellulose, xylan and lipase activities.

\section{Results \\ Soil Physicochemical Analysis}

Rhizospheric soil samples of four D. annulatum plants were analyzed and characterized on the basis of physicochemical properties such as soil $\mathrm{pH}$, salinity, moisture, temperature, organic matter, NPK, CEC and SAR (Table 1). Soil pH ranged from 8.11 to 8.56 with the highest value in plant 3 and the lowest value in plant 1, electrical conductivity (EC1:1) ranged from 3.77 to $4.65 \mathrm{dS} / \mathrm{m}$, values for soil moisture content ranged from 24.15 to $27.32 \%$, temperature ranged from 29.23 to $32.52^{\circ} \mathrm{C}$ (Table 1). The value for total organic matter was maximum in soil sample 1 (35.77) and minimum in soil sample 4 (32.29). The amounts of available $\mathrm{P}, \mathrm{K}, \mathrm{Ca}$ and $\mathrm{Mg}$ were maximum in soil sample 1 as compared to other soil samples. CEC and SAR values were maximum (73.61 mg.dm-3 and 13.51) for soil sample 2 (Table 1).

Table 1: Physical and chemical properties of rhizospheric soil samples of D. annulatum

\begin{tabular}{|c|c|c|c|c|}
\hline Parameters & D. annulatum 1 & D. annulatum 2 & D. annulatum 3 & D. annulatum 4 \\
\hline $\mathrm{pH}$ & $8.11^{\mathrm{a}}$ & $8.29^{\mathrm{ab}}$ & $8.56^{\mathrm{b}}$ & $8.35^{\mathrm{ab}}$ \\
\hline $\mathrm{EC}_{1: 1}(\mathrm{dS} / \mathrm{m})$ & $4.14^{\mathrm{ab}}$ & $3.77^{\mathrm{a}}$ & $4.19^{\mathrm{ab}}$ & $4.65^{\mathrm{b}}$ \\
\hline Moisture (\%) & $25.83^{\mathrm{ab}}$ & $24.15^{\mathrm{a}}$ & $27.32^{\mathrm{b}}$ & $25.52^{\mathrm{ab}}$ \\
\hline Temperature $\left({ }^{\circ} \mathrm{C}\right)$ & $29.23^{\mathrm{a}}$ & $32.52^{\mathrm{b}}$ & $31.01^{\mathrm{ab}}$ & $30.82^{\mathrm{ab}}$ \\
\hline Texture class & Silty loam & Silty loam & Silty loam & Silty loam \\
\hline $\mathrm{OM}\left(\mathrm{g} \cdot \mathrm{Kg}^{-1}\right)$ & $35.77^{b}$ & $33.15^{\mathrm{a}}$ & $34.55^{\mathrm{ab}}$ & $32.59^{\mathrm{a}}$ \\
\hline $\mathrm{P}\left(\mathrm{mg} \cdot \mathrm{kg}^{-1}\right)$ & $3.99^{\mathrm{ab}}$ & $3.26^{\mathrm{a}}$ & $3.82^{\mathrm{ab}}$ & $3.59^{\mathrm{ab}}$ \\
\hline $\mathrm{K}\left(\mathrm{mg} \cdot \mathrm{kg}^{-1}\right)$ & $0.76^{\mathrm{a}}$ & $0.58^{\mathrm{b}}$ & $0.65^{\mathrm{b}}$ & $0.49^{\mathrm{a}}$ \\
\hline $\mathrm{Ca}\left(\mathrm{mg} \cdot \mathrm{kg}^{-1}\right)$ & $1.70^{\mathrm{b}}$ & $1.67^{b}$ & $1.51^{\mathrm{a}}$ & $1.48^{\mathrm{a}}$ \\
\hline $\operatorname{Mg}\left(\mathrm{mg} \cdot \mathrm{kg}^{-1}\right)$ & $1.28^{\mathrm{b}}$ & $1.15^{\mathrm{a}}$ & $1.26^{\mathrm{b}}$ & $1.19^{\mathrm{a}}$ \\
\hline $\mathrm{NO}^{-3}\left(\mathrm{mg} \cdot \mathrm{kg}^{-1}\right)$ & $12.76^{\mathrm{b}}$ & $13.12^{\mathrm{b}}$ & $10.21^{\mathrm{a}}$ & $10.87^{a}$ \\
\hline $\mathrm{H}+\mathrm{Al}\left(\mathrm{mg} \cdot \mathrm{kg}^{-1}\right)$ & $67.55^{\mathrm{b}}$ & $59.32^{\mathrm{a}}$ & $61.24^{\mathrm{a}}$ & $65.87^{b}$ \\
\hline $\mathrm{V}\left(\mathrm{mg} \cdot \mathrm{kg}^{-1}\right)$ & $4.13^{\mathrm{b}}$ & $3.87^{a}$ & $4.18^{\mathrm{b}}$ & $3.76^{\mathrm{a}}$ \\
\hline $\mathrm{CEC}\left(\mathrm{mg} \cdot \mathrm{dm}^{-3}\right)$ & $68.45^{a}$ & $73.61 b$ & $72.73^{b}$ & $67.78^{a}$ \\
\hline SAR & $10.24^{\mathrm{b}}$ & $13.51 \mathrm{a}$ & $11.15^{\mathrm{a}}$ & $12.42^{\mathrm{b}}$ \\
\hline
\end{tabular}

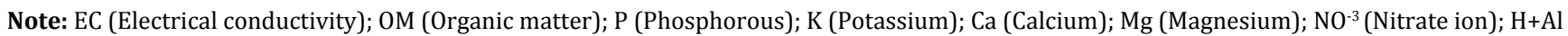
(potential acidity); V (base saturation index); CEC (Cation exchange capacity) and SAR (Sodium adsorption ratio). Letters represent statistically significant values at $5 \%$ level.

\section{Morphological and Biochemical Characterization of Haloalkaliphilic Bacterial Isolates}

A total of 41 bacterial strains were isolated from the rhizosphere and roots of $D$. annulatum by using Hap medium with high salt concentration $(3 \% \mathrm{NaCl})$ and $\mathrm{pH}(9.2)$. These isolates were identified on the basis of morphological and biochemical characterization. Out of $41,40 \%$ bacterial isolates were identified as members of genus Bacillus, $16 \%$ isolates were related to Kocuria, 12\% isolates were belonging to Exiguobacterium, $8 \%$ isolates were related to Citricoccus, $8 \%$ isolates were identified as Staphylococcus and $4 \%$ isolates were realted to Micrococcus (Fig. 1). 


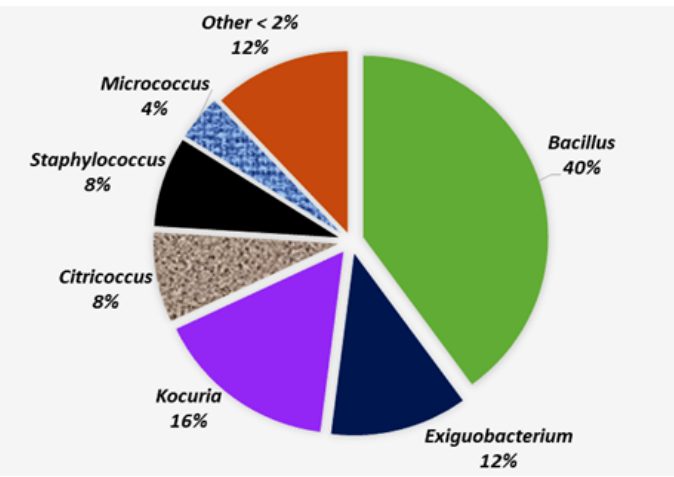

Figure 1: Relative abundance of haloalkaliphilic bacterial isolates from the rhizosphere, rhizoplane and root endosphere of $D$. annulatum

Phylogenetic Analysis of Haloalkaliphilic Bacterial Strains

On the basis of morphological and biochemical characterization, 22 bacterial isolates were selected for molecular characterization and phylogenetic analysis. Sequence analysis of 16S rRNA gene showed that 9 bacterial strains, PGRS2, PGRS7, PGRS9 and PGRS10 from the rhizosphere, PGRP3, PGRP6 and PGRP7 from the rhizoplane and PGHP2 and PGHP8 from the root endosphere of $D$. annulatum were identified as different species of Bacillus (Table 2 and Fig. 2). Three bacterial strains (PGRS1, PGRS3 and PGHP1) had 99\% similarity with Exiguobacterium mexicanum, 3 bacterial strains (PGRS5, PGRP4 and PGHP9) were related to Kocuria ( $K$. rosea and $K$. polaris), 2 bacterial strains (PGRP2 and PGHP4) showed 99\% similarity with Citricoccus alkalitolerans and one strain (PGHP5) had 99\% similarity with Staphylococcus equorum. Bacterial strains related to Oceanobacillus, Enterococcus, Virgibacillus and Micrococcus were also identified in this study (Table 2 and Fig. 2).

\begin{tabular}{|c|c|c|c|c|c|}
\hline Isolate code & Organism identified & Accession No. & $\begin{array}{l}\text { Closest type strain in NCBI } \\
\text { data base }\end{array}$ & $\begin{array}{l}\text { Sequence } \\
\text { length(bp) }\end{array}$ & Sequence similarity (\%) \\
\hline PGRS1 & Exiguobacterium & MH489029 & $\begin{array}{l}\text { E. mexicanum DSM } 6208 \\
\text { (JF505980) }\end{array}$ & 1406 & 99 \\
\hline PGRS2 & Bacillus & MH489030 & $\begin{array}{l}\text { B. pseudofirmus ATCC } \\
700159 \text { (NR_026137) }\end{array}$ & 1425 & 100 \\
\hline PGRS3 & Exiguobacterium & MH489031 & $\begin{array}{l}\text { E. mexicanum DSM } 16483 \\
\text { (JF505982) }\end{array}$ & 1365 & 99 \\
\hline PGRS5 & Kocuria & MH489032 & $\begin{array}{l}\text { K. rosea ATCC } 186 \\
\text { (KM114943) }\end{array}$ & 1412 & 99 \\
\hline PGRS6 & Oceanobacillus & MH489033 & $\begin{array}{l}\text { O. oncorhynchi DSM } 16557 \\
\text { (KJ145755) }\end{array}$ & 1305 & 100 \\
\hline PGRS7 & Bacillus & MH489034 & $\begin{array}{l}\text { B. cohnii DSM } 6307 \\
\text { (JF689927) }\end{array}$ & 1465 & 100 \\
\hline PGRS9 & Bacillus & MH489035 & $\begin{array}{l}\text { B. alcalophilus JCM } 5262 \\
\text { (NR_036894) }\end{array}$ & 1345 & 99 \\
\hline PGRS10 & Bacillus & MH489036 & $\begin{array}{l}\text { B. polygoni NCIMB } 14282 \\
\text { (NR_041571) }\end{array}$ & 1513 & 99 \\
\hline PGRS11 & Enterococcus & MH489037 & $\begin{array}{l}\text { E. durans ATCC } 19432 \\
\text { (NR_036922) }\end{array}$ & 1362 & 99 \\
\hline PGRS12 & Virgibacillus & MH489038 & $\begin{array}{l}\text { V. halodenitrificans DSM } \\
10037 \text { (HG931337) }\end{array}$ & 1473 & 100 \\
\hline PGRP2 & Citricoccus & MH489039 & $\begin{array}{c}\text { C. alkalitolerans KCTC } 19012 \\
\text { (KF322100) }\end{array}$ & 1434 & 99 \\
\hline
\end{tabular}




\begin{tabular}{|c|c|c|c|c|c|}
\hline PGRP3 & Bacillus & MH489040 & $\begin{array}{l}\text { B. alcalophilus ATCC } 27647 \\
\text { (NR_036889) }\end{array}$ & 1421 & 99 \\
\hline PGRP4 & Kocuria & MH489041 & $\begin{array}{l}\text { K. polaris CIP } 107764 \\
\text { (KF876845) }\end{array}$ & 1464 & 99 \\
\hline PGRP6 & Bacillus & MH489042 & $\begin{array}{l}\text { B. halodurans NRRL B-3881 } \\
\text { (HQ446864) }\end{array}$ & 1384 & 99 \\
\hline PGRP7 & Bacillus & MH489043 & $\begin{array}{l}\text { B. alkalinitrilicus DSM } 22532 \\
\text { (NR_044204) }\end{array}$ & 1298 & 99 \\
\hline PGHP1 & Exiguobacterium & MH489044 & $\begin{array}{l}\text { E. mexicanum DSM } 16483 \\
\text { (JF505982) }\end{array}$ & 1469 & 99 \\
\hline PGHP2 & Bacillus & MH489045 & $\begin{array}{l}\text { B. clarkii DSM } 8720 \\
\text { (KY849416) }\end{array}$ & 1405 & 99 \\
\hline PGHP4 & Citricoccus & MH489046 & $\begin{array}{l}\text { C. alkalitolerans DSM } 15665 \\
\text { (KF322104) }\end{array}$ & 1478 & 99 \\
\hline PGHP5 & Staphylococcus & MH489047 & $\begin{array}{l}\text { S. equorum ATCC } 43958 \\
\text { (AB975354) }\end{array}$ & 1394 & 100 \\
\hline PGHP6 & Micrococcus & MH489048 & $\begin{array}{l}\text { M. luteus CCM } 169 \\
\text { (KJ843153) }\end{array}$ & 1443 & 99 \\
\hline PGHP8 & Bacillus & MH489049 & $\begin{array}{l}\text { B. pseudofirmus DSM } 8715 \\
\text { (NR_026139) }\end{array}$ & 1356 & 99 \\
\hline PGHP9 & Kocuria & MH489050 & $\begin{array}{l}\text { K. rosea DSM } 11630 \\
\text { (KF177263) }\end{array}$ & 1429 & 99 \\
\hline
\end{tabular}

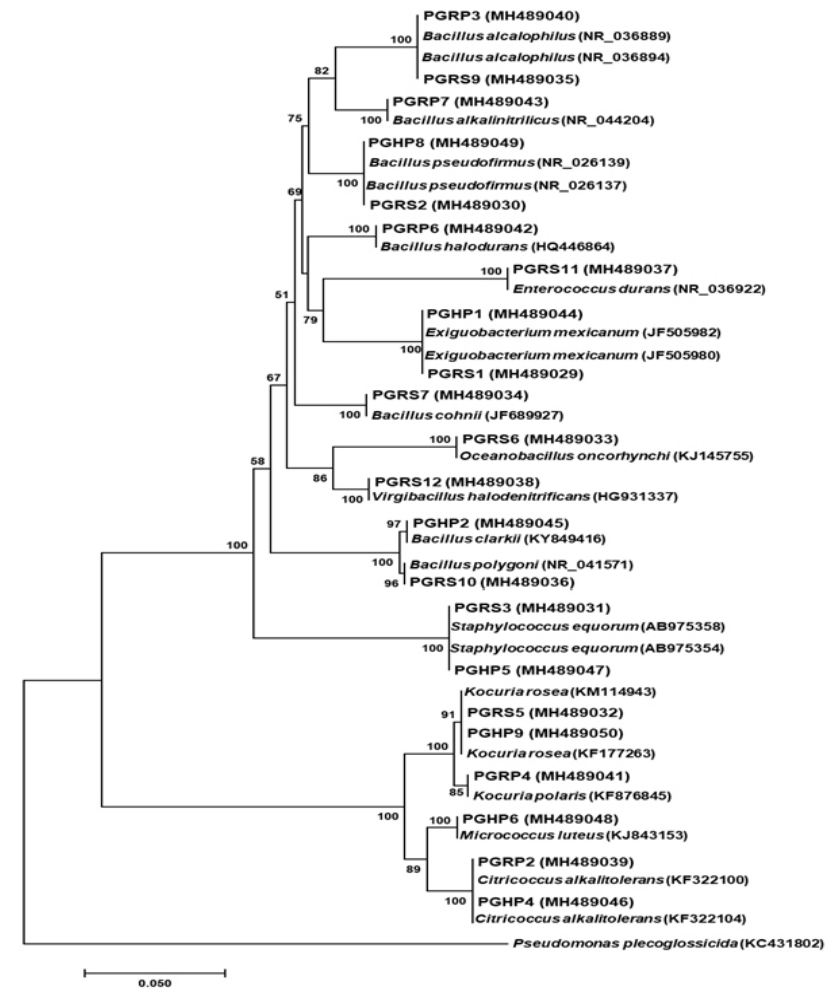

Figure 2: Phylogenetic tree based on16S rRNA gene sequences of haloalkaliphilic bacterial strains from the rhizosphere, rhizosplane and root endosphere of $D$. annulatum. The percentage of replicate trees in which the associated taxa clustered together in the bootstrap test $(1,000$ replicates) is shown next to the branches. 


\section{Phenotypic characterization of haloalkaliphilic bacterial strains}

All the strains had ability to grow at $\mathrm{pH}$ range from 8 to 12 , but only few strains were able to survive at pH 4 and 6 (Fig. 3A). Mostly strains were able to grow at salt concentrations of 3-10\%
$\mathrm{NaCl}$ but only few strains (28\%) especially members of Bacillus had ability to grow at $12 \% \mathrm{NaCl}$ concentration (Fig. 3B). All the strains could grow well at temperature 28 and $37^{\circ} \mathrm{C}$ but only 38 $\%$ bacterial strains could tolerate at 4 and $62 \%$ strains were able to grow at $42^{\circ} \mathrm{C}$ (Fig. $3 \mathrm{C}$ ).

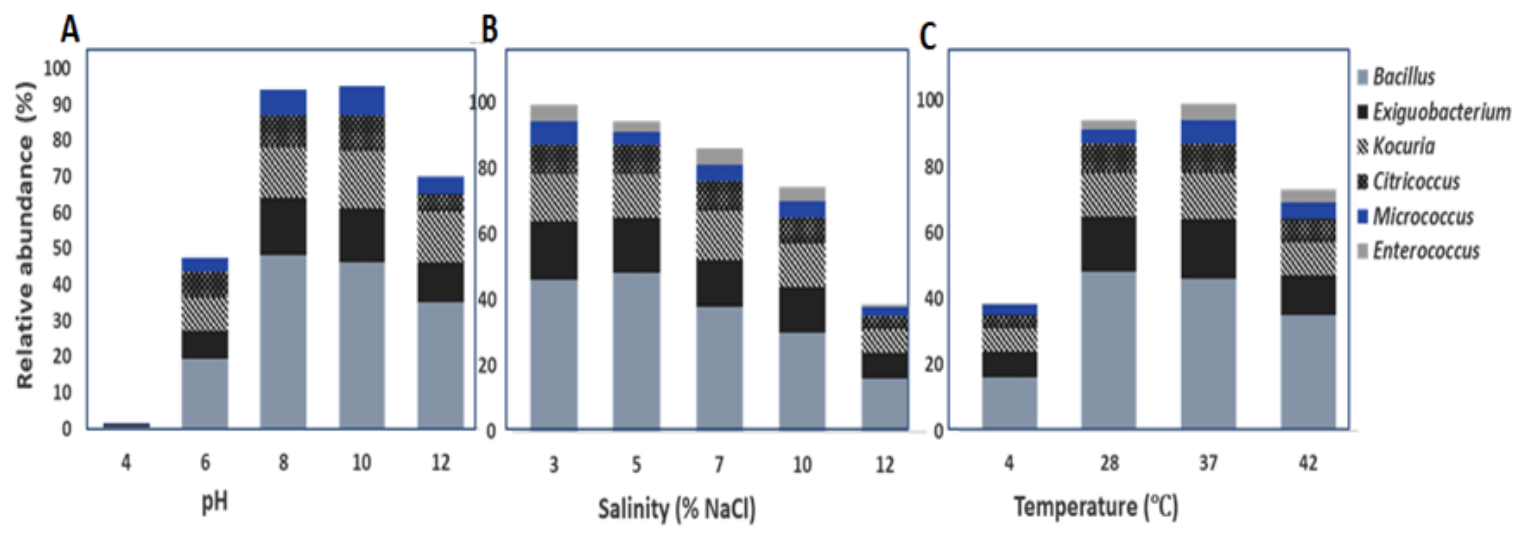

Figure 3: Phenotypic characterization of alkaliphilic bacterial isolates from the rhizosphere, rhizoplane and root endosphere of D. annulatum; (A) pH (B) salinity and (C) Temperature tolerance profile

\section{Enzyme producing ability of haloalkaliphilic bacterial} strains

Mostly haloalkaliphilic bacterial strains showed ability to degrade carbohydrates, lipids, proteins and gelatin at high salinity and $\mathrm{pH}$ (Table 3 and Fig. 4). Out of 22, sixteen bacterial strains showed positive results for protease activity, 20 strains had ability to degrade lipids, and 16 strains showed positive activity for amylase enzyme, 16 strains showed positive results for gelatinase, 14 strains were positive for cellulase activity and 14 strains showed positive results for xylanase activity (Table 3 and Fig. 4).

\begin{tabular}{|c|c|c|c|c|c|c|}
\hline Bacterial strains & Protease & Lipase & Amylase & Cellulase & Gelatinase & Xylanase \\
\hline PGRS1 & - & ++ & - & - & + & ++ \\
\hline PGRS2 & +++ & - & ++ & + & ++ & - \\
\hline PGRS3 & ++ & + & - & - & + & ++ \\
\hline PGRS5 & - & + & +++ & - & ++ & + \\
\hline PGRS6 & ++ & ++ & ++ & ++ & ++ & - \\
\hline PGRS7 & +++ & + & - & ++ & - & ++ \\
\hline PGRS9 & - & ++ & ++ & + & +++ & - \\
\hline PGRS10 & ++ & + & ++ & ++ & ++ & + \\
\hline PGRS12 & +++ & + & - & ++ & + & ++ \\
\hline PGRP2 & - & + & ++ & ++ & - & + \\
\hline PGRP3 & ++ & ++ & ++ & + & +++ & + \\
\hline PGRP4 & + & + & + & - & + & - \\
\hline PGRP6 & ++ & ++ & ++ & ++ & - & + \\
\hline PGRP7 & +++ & ++ & + & + & +++ & - \\
\hline
\end{tabular}




\begin{tabular}{|c|c|c|c|c|c|c|}
\hline PGHP1 & + & + & - & - & + & ++ \\
\hline PGHP2 & ++ & ++ & + & ++ & ++ & ++ \\
\hline PGHP4 & - & + & ++ & + & - & - \\
\hline PGHP5 & + & + & + & + & - & + \\
\hline PGHP6 & ++ & ++ & ++ & - & - & +++ \\
\hline PGHP8 & ++ & ++ & + & ++ & ++ & - \\
\hline PGHP9 & - & + & ++ & - & + & ++ \\
\hline
\end{tabular}

Note: -, no activity; +, low activity; ++, medium activity; +++, high activity

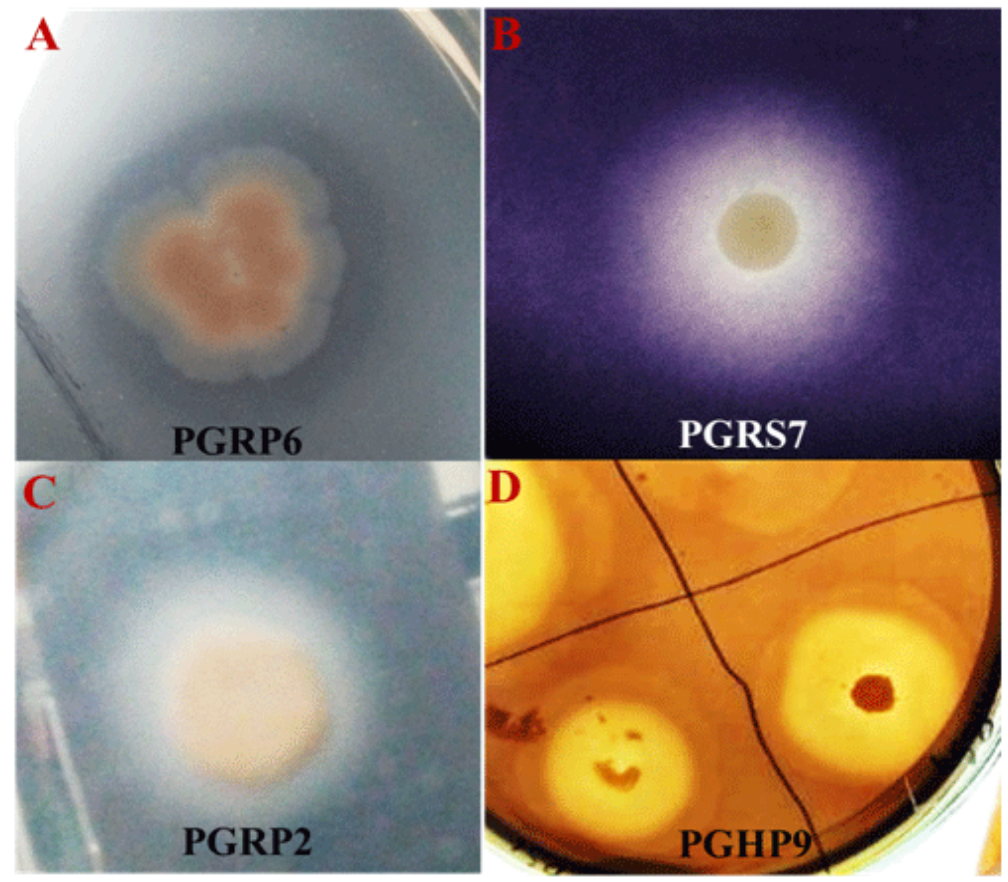

Figure 4: Enzyme assays for haloalkaliphilic bacterial strains from the rhizosphere, rhizoplane and root endosphere of D. annulatum using a drop spot technique; (A) Protease (B) Amylase (C) Lipase and (D) Cellulase

\section{Discussion}

High $\mathrm{pH}$ and salinity present a multifold challenge to all organisms in terms of ionic disequilibria and perturbed osmotic balance. Microorganisms that isolated and characterized from highly saline and saline-sodic soils have adapted special genetic and morphological modifications to survive under such extreme conditions [35, 36]. Here, we reported haloalkaliphilic bacterial diversity from the rhizosphere, rhizoplane and root endosphere of a halophyte (D. annulatum). The isolated bacterial strains were also screened for production of industrially important enzymes such as amylases, proteases, lipases, cellulases and gelatinase.

A total of 22 haloalkaliphilic bacterial strains have been identified from the rhizosphere and roots of D. annulatum. Phylogenetic analysis showed that these isolates were related to nine different bacterial genera Bacillus, Exiguobacterium, Kocuria, Citricoccus, Staphylococcus, Enterococcus, Oceanobacillus, Virgibacillus and Micrococcus (Table 2). Previous studies on the isolation of haloalkaliphilic bacterial strains from Soda Lake Magadi (Kenya) showed that Bacillus, Exiguobacterium and Halomonas were the dominant genera identified from these environments [5, 37]. The abundance of Gram positive bacteria (Bacillus, Exiguobacterium, Kocuria, and Staphylococcus) is attributed to their cell wall and endospore formation in Bacillus enable them to survive in hypersaline and saline-sodic environments. Members of Actinobacteria Kocuria, Citricoccus and Micrococcus identified in this study have been previously reported from hypersaline soil of halophytes and Texcoco Lake $[38,39]$.

Bacterial isolates characterized in this study were alkaliphilic and moderately halophilic in nature. More than $87 \%$ strains were able to grow at $\mathrm{pH}$ more 10 , salt concentrations $5-10 \%$ and temperature $28-42^{\circ} \mathrm{C}$. Previous studies also reported that alkaliphiles, moderately halophiles and mesophiles are more abundant as compare to extremely halophilic and thermophilic 
bacteria in different soils [38, 40]. Halophilic strains from the groups, Virgibacillus and Oceanobacillus show optimum growth at salt concentration $5-10 \% \mathrm{NaCl}$ and $28-37{ }^{\circ} \mathrm{C}$ [41].

Most of the bacterial strains showed ability to degrade different organic compounds such as carbohydrates, lipids, proteins and gelatin. More than $90 \%$ bacterial strains showed lipase activity, $73 \%$ bacterial strains showed proteolytic activity, $72 \%$ strains had ability to degrade carbohydrates, $73 \%$ strains showed positive results for gelatinase activity, $64 \%$ strains had ability to degrade cellulose and $63 \%$ strains showed xylanase activity (Table 3). Alkaliphilic, halophilic and mesophilic bacteria isolated from different saline and saline-sodic environments showed their ability to produce different industrially important enzymes such as amylases, proteases, lipases, gelatinase and xylanase $[9,11]$. Enzymes produced by haloalkaliphilic bacteria have structural and catalytic properties to function properly even at high salinity, pH and temperature [42]. Lipase and protease producing alkaliphilic and halophilic bacteria have been previously isolated marine environment and food sources such as fish sauce [37, 43]. Halophilic bacterial strains related to Bacillus and Oceanobacillus are known to be a good source of different hydrolytic enzymes such as $\alpha$-amylases, lipase, protease and xylanases [14, 42]. Members of Actinobacteria Citricoccus, Kocuria and Micrococcus have been well known for production of lipases, cellulases, amylases and gelatinase [39, 44]. Haloalkaliphilic cellulases and xylanases have been produced by different alkaliphilic and halophilic bacteria such as Kocuria, Bacillus and Staphylococcus [45]. Members of Exiguobacterium have been isolated from hypersaline tropical soils. These bacteria are able to grow at high $\mathrm{pH}$ and considered as good source of alkaliphilic enzymes such as proteases, lipases, cellulases and gelatinase $[42,46]$.

\section{Conclusion}

This study was the first report of its kind that deals with characterization of haloalkaliphilic bacteria from the rhizosphere and roots of $D$. annulatum. Twenty two haloalkaliphilic bacterial strains were identified on the basis of 16S rRNA gene analysis from the rhizosphere, rhizoplane and root endosphere. Nine strains showed more than $99 \%$ similarity with different species of Bacillus. Other dominant bacterial genera included Kocuria, Exiguobacterium, Citricoccus, Oceanobacillus and Staphylococcus was identified in this study. Most of the bacterial strains showed positive results for industrially important enzymes such as amylases, cellulases, proteases, lipases, gelatinase and xylanases. The ability of these bacterial strains to survive at high salinity, $\mathrm{pH}$ and temperature showed their potential biotechnological applications especially as a source of various enzymes.

\section{Acknowledgement}

We are highly thankful to Higher Education Commission [Project \# HEC (FD/2012/1843)] for research grant.

\section{References}

1. Litchfield CD, Gillevet PM. Microbial diversity and complexity in hypersaline environments: a preliminary assessment. J Ind Microbiol Biotechnol. 2002;28(1):48-55.

2. Mukhtar S, Ishaq A, Hassan S, Mehnaz S, Mirza MS, Malik KA. Comparison of microbial communities associated with halophyte (Salsola stocksii) and non-halophyte (Triticum aestivum) using culture-independent approaches. Pol J Microbiol. 2017;66(3):375386.

3. Ahmad R. Halophytes in Agriculture. DRIP Newsletter, Drainage and Reclamation Institute of Pakistan.1993;14(3).

4. Khan MA, Ansari R, Ali H, Gul B, Nielsen BL. Panicum turgidum, potentially sustainable cattle feed alternative to maize for saline areas. Agri Ecosys Environ. 2009;129(4):542-546.

5. Govender L, Naidoo L, Setati ME. Isolation of hydrolase producing bacteria from Sua pan solar salterns and the production of endo-1, 4-b-xylanase from a newly isolated haloalkaliphilic Nesterenkonia sp. Afr J Biotechnol. 2009; 8(20):5458-5466.

6. Hidri DE, Guesmi A, Najjari A, Hanen Cherif, Besma Ettoumi, Chadlia Hamdi, Abdellatif Boudabous, et al. Cultivation-dependant assessment, diversity, and ecology of haloalkaliphilic bacteria in Arid Saline Systems of Southern Tunisia. Bio Med Research Inte. 2013;1:1-16.

7. Takami H, Inoue A, Fuji F, Horikoshi K. Microbial flora in the deepest sea mud of the Mariana Trench. FEMS Microbiol Lett. 1997;152(2):279-285.

8. Horikoshi K. Alkalophiles: Some applications of their products for biotechnology. Microbiol Mol Biol Rev. 1999; 63(4): 735-750.

9. Jones BE, Grant WD. Microbial diversity and ecology of alkaline environments. Adaptation to Exotic Environments. Dordrecht: Kluwer Academic Publishers. 2000:177-190.

10. Bowers KJ, Mesbah NM, Wiegel J. Biodiversity of poly-extremophilic Bacteria: Does combining the extremes of high salt, alkaline $\mathrm{pH}$ and elevated temperature approach a physico-chemical boundary for life? Saline Sys. 2009;5:1-9. doi: 10.1186/1746-1448-5-9

11.Lundberg DS, Lebeis SL, Paredes SH, Yourstone S, Gehring J, Malfatti S, Tremblay J, Engelbrektson A, Kunin V. Defining the core Arabidopsis thaliana root microbiome. Nature. 2012;488:86-90.

12.Liu M, Cui Y, Chen Y, Lin X, Huang H, Bao S. Diversity of Bacillus-like bacterial community in the sediments of the Bamenwan mangrove wetland in Hainan, China. Can J Microbiol. 2017;63(3):238-245. doi: 10.1139/cjm-2016-0449

13.Taprig T, Akaracharanya A, Sitdhipol J, Visessanguan W, Tanasupawat S. Screening and characterization of proteaseproducing Virgibacillus, Halobacillus and Oceanobacillus strains from Thai fermented fish. J appl pharm sci. 2013; 3(2):25-30.

14. Horikoshi K. Enzymes isolated from alkaliphiles. Extremophiles Handbook. 2011:163-181.

15.Fujinami S, Fujisawa, M. Industrial application of alkaliphiles and their enzymes - past, present and future. Environ Technol. 2010;31(8-9):845-856. doi: 10.1080/09593331003762807

16. Krishna P, Arora A, Reddy MS. An Alkaliphilic and Xylanolytic strain of Actinomyctes. World J Microbiol Biotechnol. 2008;24(12):30793085. 
17. Ahmad K, Hussain M, Ashraf M, Luqman M, Ashraf MY, Khan ZI. Indigenous vegetation of Soon valley at the risk of extinction. PakJ Bot. 2007;39(3):679-690.

18. Anderson JM, Ingram JS. Tropical Soil Biology and Fertility: A Handbook of Methods. 2nd ed. CAB International, Wallingford, UK. 1993:93-94.

19. Adviento-Borbe MA, Doran JW, Drijber RA, Dobermann, A. Soil electrical conductivity and water content affect nitrous oxide and carbon dioxide emissions in intensively managed soils. J Environ Qual. 2006;35(6):1999-2010.

20.Walkley A, Black IA. An examination of degtjareff method for determining soil organic matter and a proposed modification of the chromic acid titration method. Soil Sci. 1934;37(1):29-37.

21. Schneegurt MA. Media and conditions for thegrow th of halophilic and halotolerant bacteria and archaea. In: Vreeland RH (ed) Advances in understanding the biology of halophilic microorganisms. Springer, Dordrecht. 2012;35-58.

22. Malik KA, Bilal R, Mehnaz S, Rasool G, Mirza MS, Ali S. Association of nitrogen-fixing, plant grow th promoting rhizobacteria (PGPR) with kallar grass and rice. Plant Soil. 1997;194(1-2):37-44.

23.Somasegaran P. Handbook for Rhizobia: Methods in Legume Rhizobium Technology. Springer-Verlag, cop. New York. 1994.

24. Winnepenninckx B, Backeljau T, de Wachter R. Extraction of high molecular weight DNA from molluscs. Trends Genet. 1993;9(12):407412.

25.Tan ZY, Xu XD, Wan ET, Gao JL, Romer EM, Chen WX. Phylogenetic and genetic relationships of Mesorhizobium tianshanense and related Rhizobia. Int J Sys Bacteriol. 1997;47(3):874-879.

26.Varian H. Bootstrap tutorial. Math J. 2005;9:768-775.

27. Tamura K, Nei M, Kumar S. Prospects for inferring very large phylogenies by using the neighbor-joining method. Proc Natl Acad Sci USA. 2004;101(30):11030-11035.

28. Kumar S, Stecher G, Tamura K. MEGA7: Molecular Evolutionary Genetics Analysis version 7.0 for bigger datasets. Mol Biol Evol. 2016;33(7):1870-1874. doi: 10.1093/molbev/msw054

29. Bhadekar RK, Jadhav VV, Yadav A, Shouche YS. Isolation and cellular fatty acid composition of psychrotrophic Halomonas strains from Antarctic sea water. Eur Asia J BioSci. 2010;4:33-40.

30.Gupta P, Samant K, Sahu A. Isolation of cellulose-degrading bacteria and determination of their cellulolytic potential. Inter J Microbiol. 2012;20:28-35.

31. Kumar KV, Srivastava S, Singh N, Behl HM. Role of metal resistant plant growth promoting bacteria in ameliorating fly ash to the growth of Brassica juncea. J Haz Mat. 2009;170(1):51-57. doi: 10.1016/j.jhazmat.2009.04.132

32.Pitt TL, Dey D. A method for the detection of gelatinase production by bacteria. J Appl Microbiol. 1970;33(4):687-691.

33. Sierra G. A simple method for the detection of lipolytic activity of micro-organisms and some observations on the influence of the contact between cells and fatty acid substrates. A Van Leeuw J Microbiol. 1957;23(1):15-22.
34.Ghio S, DiLorenzo GS, Lia V, Talia, Cataldi A, Grasso D, Campos E. Isolation of Paenibacillus sp. and Variovorax sp. strains from decaying woods and characterization of their potential for cellulose deconstruction. Int J Biochem Mol Biol. 2012;3(4):352-364.

35.Sharma A, Singh P, Kumar S, Kashyap PL, Srivastava AK, Chakdar $\mathrm{H}$, et al. Deciphering Diversity of Salt-Tolerant Bacilli from Saline Soils of Eastern Indo-gangetic Plains of India. Geomicrobiol J. 2015;32(2):170-180.

36. Mukhtar S, Mirza MS, Mehnaz S, Mirza BS, Malik KA. Diversity of Bacillus-like bacterial community in the rhizospheric and nonrhizospheric soil of halophytes (Salsola stocksii and Atriplex amnicola) and characterization of osmoregulatory genes in halophilic Bacilli. Can J Microbiol. 2018;64(8):567-579. DOI: 10.1139/cjm-2017-0544

37. Nyakeri EM, Mwirichia R, Boga H. Isolation and characterization of enzyme producing bacteria from Soda Lake Magadi, an extreme soda lake in Kenya. J Microbiol Exp. 2018;6(2):57-68.

38. Mukhtar S, Mirza MS, Awan HA, Maqbool A, Mehnaz S, Malik KA. Microbial diversity and metagenomic analysis of the rhizosphere of Para Grass (Urochloa mutica) growing under saline conditions. Pak J Bot. 2016;48(2):779-791.

39. Marisela YSP, Valenzuela-Encinas C, Dendooven L, Marsch R, Gortáres-Moroyoqui P, Estrada-Alvarado MI. Isolation and phylogenic identification of soil haloalkaliphilic strains in the former Texcoco Lake. Inte J Environ Health Res. 2014;24(1):82-90. doi: 10.1080/09603123.2013.800957

40.Irshad A, Ahmad I, Kim SB. Culturable diversity of halophilic bacteria in foreshore soils. Braz J Microbiol. 2014;45(2):563-571.

41. DasSarma S, DasSarma P. Halophiles and their enzymes: negativity put to good use. Curr Opin Microbiol. 2015;25C: 120-126. doi: 10.1016/j.mib.2015.05.009

42. Kumar S, Karan R, Kapoor S, Singh SP, Khare SK. Screening and isolation of halophilic bacteria producing industrially important enzymes. Braz J Microbiol. 2012;43(4):1595-1603. doi: 10.1590/ S1517-838220120004000044

43.Phrommao E, Rodtong S, Yongsawatdigul J. Identification of novel halotolerant bacillopeptidase F-like proteinases from a moderately halophilic bacterium, Virgibacillus sp. SK37. J Applied Microbiol. 2011;110(1):191-201. doi: 10.1111/j.1365-2672.2010.04871.x

44.Mukhtar S, Zaheer A, Aiysha D, Malik KA, Mehnaz S. Actinomycetes: A source of industrially important enzymes. J Proteomics Bioinform. 2017;10:316-319.

45. De Lourdes MM, Pérez D, García MT, Mellado E. Halophilic bacteria as a source of novel hydrolytic enzymes. Life. 2013;3(1):38-51.

46.Anbu P, Annadurai G, Hur BK. Production of alkaline protease from a newly isolated Exiguobacterium profundum BK-P23 evaluated using the response surface methodology. Biologia. 2013;68(2):186193. 